\title{
Learner councils in South African schools: adult involvement and learners' rights
}

Frances Hunt

Accepted proof (version 2)

After copy editing this paper was subsequently published in: Hunt, F. (2014) Journal of Education, Citizenship and Social Justice, 9 (3), 268-285.

Key words: learner councils; school councils; rights; active citizenship; student voice; South Africa; schooling relations;

\begin{abstract}
Each secondary school in South Africa is legally obliged to establish a representative council of learners (RCL), a democratically elected, learner-only council. This article looks at how the RCLs are realised in practice in four secondary schools. Three research questions focus on the practice of RCLs, how they engage with learner rights and the role adults play in mediating RCLs. The paper explores whether RCLs are spaces where learners actively pursue human rights agendas where inequalities and injustices exist. It adds to a body of work exploring the enactment of the UNCRC and Constitution in South Africa and explores the complexity of schooling relations which shape their potential.
\end{abstract}




\section{Introduction}

In South Africa each secondary school is legally obliged to establish a representative council of learners (RCL), a learner-only council that is democratically elected to represent learners in the school. This article looks at how the RCLs are realised in practice in four secondary schools in Western Cape, each with a different geographic location and historical background. It focuses on the different constructions and functions of the four RCLs. The paper has a particular focus on the extent to which RCLs are being used by learners (and staff) to engage with learners' rights and whether this has resulted in changes in access to rights. It also interrogates in more detail the relationships between staff and learners that help shape the councils.

In South Africa the Bill of Rights in the Constitution (RSA, 1996) affords all citizens a set of civic, political and socio-economic rights to which they have legal entitlements as members of the state, as well as responsibilities to help ensure the rights of others. South Africa is also a signatory to the UN Convention on the Rights of the Child (UN, 1989) and has a Children's Act (RSA, 2006) which aims to clarify children's rights as laid down in the Constitution. Education policy reinforces these rights with schools tasked with the promotion of equality, equity and democracy. The paper explores whether RCLs are places where learners actively pursue rights agendas where inequalities and injustices exist.

Proponents of learner councils include in their benefits, improving learners' life/active citizenship skills (e.g. speaking, teamwork, self-esteem), increasing learner voice, improving relations between staff and learners and school improvement (Whitty and Wisby, 2007). At the same time research on school councils ${ }^{1}$ indicates they often fail to impress in practice (Baginsky \& Hannam, 1999; Fielding, 1973; Halstead \& Taylor, 2000; Hannam, 2003; Pryor et al., 2003; Taylor \& Johnson, 2002). While there is research on school councils and learner voice, there is little evidence of learners claiming other rights via councils ${ }^{2}$. Indeed, Hannam (2003: 1) suggests few councils are 'effective,' whilst the majority are tokenistic (many failing to involve the majority of learners).

In South Africa, while each secondary school has a 'learner' council, research on their practices and impacts at school level is very limited. This paper goes some way to filling this gap, providing detailed insight into learner councils in four schools. It also adds a body of work exploring the enactment of the Constitution (and other rights treaties) and the complexity of schooling relations which might interact with their potential (and that of learners). Three research questions emerged through data analysis and form the basis of inquiry for the paper:

1. How are the RCLs working in practice in the four case study schools?

2. In what ways do the RCLs engage with learners' rights?

3. What role do adults play in mediating RCLs and why?

The article starts with historic and policy contexts of RCLs in South Africa. It highlights literature on learner voice, learner rights and adult-learner relations. After a methodological section, the data analysis section responds to the three research questions. Final remarks are made and conclusions drawn.

\footnotetext{
${ }^{1}$ I use the term school council here in a wider (international) sense. RCLs are South African only.

${ }^{2}$ An exception might be in Wales, where (obligatory) school councils emphasise a rights-based approach, including a policy which states pupils are able to claim rights, but should understand and accept the responsibilities arising from them (Whitty and Wisby, 2007). 


\section{Background context}

School-based councils have, like the education system as a whole in South Africa, different historical context linked to 'race ${ }^{3}$ '. Under apartheid student representative councils (SRCs) were unofficial learner-led bodies established in some (mainly 'black', but also 'indian' and 'coloured') schools to co-ordinate struggle efforts. They were linked to the struggle movement and often pursued a rights agenda (e.g. to end discrimination, inferior education and corporal punishment). SRCs 'demanded a say in matters that affected learners, and operated in line with democratic principles' (Carr, 2005: 63). 'White' schools were more likely to have school councils, traditional and formal bodies which included staff members, with prefect systems being concerned with discipline and enforcing established agendas.

RCLs were established in policy through the South African Schools Act (SASA) (DoE, 1996). SASA has been described as a 'compromise solution' which attempted to acknowledge and address South Africa's diverse schooling histories (Naidoo, 2005: 30). Certainly the learnerled nature of RCLs lends itself more to some South African histories, than others. In policy, RCLs are to be the only recognized, legal representative body for learners in schools. They are to be democratically-elected learner-led council which represent learners and their concerns within the school. Two members of the RCL are to sit on the School Governing Body, alongside parents and staff. Prefect systems may operate in schools, but only as a subcommittee of the RCL.

There is limited guidance provided by policy makers on how RCLs should function and their scope. Western Cape Education Department (WCED) (1997 and 20034) provides some detail on how RCL members should be elected, their composition and intended functions. Education Human Resources (1999) gives some information on the goals, roles and the responsibilities of RCLs. Yet, messages from these guidance documents seem underdeveloped and lacking in ambition (Mavubula, 2009; Phaswana, 2010). Within them, RCLs are tasked with maintaining order in schools, promoting good relations and communication, setting positive examples, supporting the education programme and maintaining and refining the traditions of the school. In this sense, RCLs are not political bodies, they do not give voice to inequality or inadequacy and they are not able to make informed decisions. Indeed it might be questionable as to whether their remit, as outlined in the guidance documents, supports learners' right to voice (see: Section 3 for further information).

A lack of directive could allow for innovative and interesting practice at the school level, it could also enable the tokenistic and ineffective councils Hannam (2003) describes in the UK. While there is research on learners' involvement in school governing bodies in South Africa (Bray and Moses 2011; Carrim, 2011), there is only limited research on RCLs, and how that policy is played out in practice. Research by Carr (2005), Carr and Williams (2009) and Thuthukani Solutions (2003) explored how RCLs were functioning in Western Cape via questionnaires completed by RCL learner representatives and school staff and Phaswana (2010) uses focus groups with RCLs to look at their (learning) experiences. This research is different because it provides in-depth insight into RCLs taken from meeting observations and interviews with a

\footnotetext{
${ }^{3}$ The term race and descriptors of 'race' will be used through this article. I see the term 'race' as a social construct, but for many in South Africa it may exist 'as an effect of the very way in which we think, know and inhabit the world' (Ahmed, 2002, quoted in Byrne, 2005:16). Through the text I have used the apartheid categorisations of race (that is 'black', 'coloured', 'indian' and 'white') in order to describe South Africa's population groups. I have chosen to use these racial categorisations, not because I see any biological basis for differentiation, but because I wanted to reflect on some of the changes and continuities within South African schooling.

${ }^{4}$ This 2003 document does not form the basis for discussion in this text as was only relevant for the second stage of field work. However, no changes in RCLs had discernibly taken place between fieldwork in 2002 and 2003, nor was any reference made by research participants to Provincial Gazette Extraordinary 5946 in 2003.
} 
range of school stakeholders. Other studies have not done this. It complements previous studies adding to understandings of how RCLs work in practice.

\section{Learners' rights, school councils and the role of adults}

South African learners have a range of rights as laid out in the Constitution (RSA, 1996), the UNCRC (UN, 1989) and the Children's Act (RSA, 2006). Central to this paper is a focus on learners' right to voice which shapes analysis, but I also explore whether learners use the formal space of councils to access other rights. How adults interact with learners in these spaces and thus shape access to rights is also important.

Article 12 of the UNCRC (as well as Article 10 of the Children's Act) outlines children's right to express a view and for that view to be given due consideration. Lundy (2007) has given considerable thought to this and argues that children's voice is a legal obligation of schools. She contests that for the successful implementation of Article $12^{5}$ four separate factors need to be considered:

- Space: Children must be given the opportunity to express a view in a safe space, free from the fear of rebuke or reprisal. These spaces should be inclusive and welcoming for all children to participate.

- Voice: Children must be facilitated to express their views, so long as they are capable of forming their own views. Age and maturity of children should not preclude them from doing this.

- Audience: Children's views must be listened to by those involved in and have ultimate influence over decision making processes. This might involve formalising channels of communication for children's views.

- Influence: Children's views are to be given due weight and must be acted upon, as appropriate. A definition of 'due' weight is linked to the 'age and maturity' of the child, and given that this is usually dependent on adults' perceptions a child's capacity, it makes the realisation of 'influence' more complex. Lundy suggests, at the very least, children should be told what decision was made, how their views were regarded and the reasons why action has proceeded in a certain way (and includes the possibility of children's views fully determining some issues) (Lundy, 2007: 933-7).

But, as Lundy (2007:931) suggests, 'one of the inherent difficulties with this is that the initial goodwill can dissipate when the rhetoric needs to be put into practice'. Indeed, research in South Africa has shown that while learners have legal rights, access to substantive rights (Lister, 1998) for many is lacking (Hunt, 2007, 2011). The role of adults in mediating children's rights within schools (and school councils) is seen as key, particularly as some are seen to have a vested interest in not complying with Article 12 (Lundy, 2007:929).

Wyness (2001) divides children's rights' literature into rights to welfare and their rights to selfdetermination. Children's rights' to welfare reinforces adults hold over children, as it assumes they have a responsibility to ensure children's welfare needs are met (e.g. healthcare, education). However, children's rights to self-determination take obligations and powers away

\footnotetext{
5 There is also potential interplay with other UNCRC initiatives e.g. Article 2 (non-discrimination); Article 3 (best interests); Article 5 (right to guidance); Article 13 (right to seek, receive and impart information); and Article 19 (protection from abuse).
} 
from adults, with children having a right to make their own decisions. Wyness (2001:196) suggests, these kinds of children's rights threaten the protective and paternalist roles of adults. So, while learners can potentially claim rights to welfare and self-determination via spaces such as learner councils, it appears the right to self-determination, could potentially be problematic to perceptions of adult authority.

Wyness (2009: 396 drawing on research by Moss and Petrie, 2002) explores the nature of 'children's space' in the context of adult-child relations. Here children's spaces are set within the 'more conventionally defined structures of children's place' within the social structure. This suggests that while councils (space) might have been established to give learners a voice in schools, that voice is only heard within social structures which prioritise adults' voices over children's (place). Bragg (2007: 344) claims by creating space for voice there might be: 'shifting power relations that have accorded learners their new authority to speak,' but, 'student voice is not unmediated, but guided, facilitated and supervised through specific techniques that delimit what can be said, and how speakers conceive of themselves.... (Bragg, 2007:349).

Literature also shows how adults attempt to mediate the content of 'children's spaces.' Wyness (2009: 403) describes the tension between adult and learners' priorities, whereby children's voices are not valued 'as a set of interests reflecting their current positions as pupils', but rather 'measured against moral, social and educational trajectories that constructed the pupils as investments in future.' He provides an example of how this worked out in the context of one youth council:

adult involvement in children's participation was ... a complex process of supporting children and young people's attempts at articulating their interests, and in many instances trying to re-articulate these interests and bring them in line with the relevant dominant adult agendas (Wyness, 2009: 403).

Franklin (1989:57) suggests the denial of children's rights to participation are made because of the perception that children are incapable of making reasoned and informed decisions and they lack the wisdom born of experience and in their choices are likely to make mistakes. He collates the argument of age to competence:

The underlying concern is that children might lack the abilities necessary to exercise their rights. However, if the argument is really about competence and not age, then it is not children who should be excluded but the incompetent (Franklin, 1989:57).

Research from South Africa (Bray and Moses, 2011; Carrim, 2011; Hunt; 2007, 2011) highlights this tension, with "children from a variety of backgrounds state(ing) that they are seldom asked their opinion, listened to, respected or taken seriously by adults within the home and beyond' (Bray and Moses, 2011:13). Moreover, 'the realisation of participatory democracy $\ldots$ at the local levels of schools in South Africa is still far from where it could be' (Carrim, 2011:80).

These themes of rights and adult-learner relations will be picked up through the article, in the next section I provide the methodological approach.

\section{Methodology}

In terms of data collection I adopted a collective case study approach, with each case study a concentrated inquiry into its single case (Stake, 1994:87), and simultaneously gathered data 
from participating schools. Through the use of case studies I do not provide an account which is comprehensive or complete, but rather an account which is 'perspective-bound and partial' (Usher, 1996: 30); a 'textual construction' (Usher, 1996:30) of my take on the data collected. The case study approach provides in-depth, qualitative studies of schools at particular times, and yet there is wider relevance outside the case. Bray and Moses (2011) highlight the need for contextual location of children's participation which draws attention to socio-political, cultural and historical factors.

The four state secondary schools were located in Cape Town and I visited them twice over a period of five months in 2002 and 2003 (for an explanation of continued relevance of the data see footnote ${ }^{6}$. The participating four schools each had a different 'racial' categorisation under apartheid and remained substantially different in terms of facilities, the social class/racial intake of learners, achievement levels and staff-learner ratios. These differentiations continue to exist.

The schools have been labelled A, B, C and D and summary information about the schools is provided in Table 1. Table 1 also provides a brief indication of the historical spaces for learner voice (pre-RCLs) and whether learners were seen to be actively engaged in political spaces (as drawn from interviews with teachers and former learners), to identify if changes have been made.

Table 1: Summary information on case study schools

\begin{tabular}{|c|c|c|c|c|}
\hline & School A & School B & School C & School D \\
\hline Status under apartheid & ‘Black' school & $\begin{array}{l}\text { 'Coloured' } \\
\text { school }\end{array}$ & 'Indian' school & 'White' school \\
\hline Number of teachers & 47 & 37 & 40 & 48 \\
\hline Number of learners & c. 1600 & c. 1200 & c. 1300 & c. 900 \\
\hline $\begin{array}{l}\text { Racial breakdown of } \\
\text { learners (ss) }\end{array}$ & $\begin{array}{l}100 \% \text { black } \\
\text { ss. }\end{array}$ & $\begin{array}{ll}\text { c. } & 70 \% \\
\text { coloured; } & 30 \% \\
\text { black ss. } & \\
\end{array}$ & $\begin{array}{l}\text { c. } 60 \% \text { Indian; } \\
40 \% \text { coloured; } \\
\text { < } 20 \text { black ss. }\end{array}$ & $\begin{array}{l}\text { c. } 60 \% \text { white; } \\
30-40 \% \text { coloured / Indian; } \\
<5 \% \text { black ss. }\end{array}$ \\
\hline Racial breakdown of staff & $\begin{array}{ll}43 \text { black, } 3 \\
\text { coloured, } & 1 \\
\text { Indian. } & \end{array}$ & $\begin{array}{l}32 \text { coloured, } 5 \\
\text { black. }\end{array}$ & $\begin{array}{lr}21 \text { Indian, } & 17 \\
\text { coloured, } & 2 \\
\text { black. } & \end{array}$ & 46 white, 1 coloured. \\
\hline $\begin{array}{l}\text { School fees (Rand) per } \\
\text { year } 2002\end{array}$ & 150 & 320 & 400 & 8100 \\
\hline $\begin{array}{l}\text { Endorsement } \text { rate }^{7} 2002 \\
\text { (as \% of the number of } \\
\text { learners who passed) }\end{array}$ & $2 \%$ & $14 \%$ & $50 \%$ & $94 \%$ \\
\hline
\end{tabular}

\footnotetext{
${ }^{6}$ While data was collected from schools in 2002 and 2003 I would suggest the data has continued relevance for the following reasons. 1) At a school level substantial changes in demographic intake and school ethos in the four schools are unlikely to have occurred. With the exception of School D, all schools have the same head teacher and many of the teachers are still present. In School $D$ the website suggests the rhetoric of the school remains the same. Results patterns are similar as those highlighted in Table One (with a slight improvement of results in School A) and school fee rates are remain proportionately similar (WCED, 2013). 2) At a district level there have not been large changes in demographic contexts of the schools. Comparing demographic information about the suburbs (City of Cape Town, 2011; City of Cape Town, 2001) shows little substantial change (apart from the suburb of School A - which shows some improvements in access to housing and amenities). 3) From a research perspective there remains a dearth of research on RCLs in schools in South Africa. Arguments explored in the text around children's voice, adult-child relations and children's access to rights remain relevant and are evident in recent research (e.g. Carrim, 2011, Bray and Moses, 2011) and continue to be seen as issues that remain under-researched. There seems little evidence of change in schools around these issues (Carrim, 2011; Bray and Moses, 2011; Jamieson et al, 2011; Pendlebury, 2011). Indeed, Bray and Moses (2011:13) claim: 'children are left with a de facto oppressive situation and few mechanisms for engaging power structures'.4) Where change has occurred in schools on issues of voice and rights, it is not through a sea-change in public opinion, but through the action of special interest or advocacy groups who use their legal mandate to champion a particular cause (Bray and Moses, 2011:8). This has not happened in relation to RCLs or learner voice.

${ }^{7}$ Endorsement usually enables university entry.
} 


\begin{tabular}{|l|l|l|l|l|}
\hline $\begin{array}{l}\text { Historical engagement } \\
\text { with SRC/school council }\end{array}$ & SRC No SRC & No SRC & School council \\
\hline $\begin{array}{l}\text { Learners' historical } \\
\text { engagement in 'political } \\
\text { spaces' }\end{array}$ & $\begin{array}{l}\text { Active in } \\
\text { struggle } \\
\text { politics. }\end{array}$ & $\begin{array}{l}\text { Learners mainly } \\
\text { non-active in } \\
\text { struggle. }\end{array}$ & $\begin{array}{l}\text { Learners } \\
\text { mainly non- } \\
\text { active in } \\
\text { struggle. }\end{array}$ & $\begin{array}{l}\text { Learners engage with } \\
\text { issues and debate (though } \\
\text { constrained by external } \\
\text { authority). }\end{array}$ \\
\hline
\end{tabular}

Within the case study schools I interviewed RCL members (representatives and chairs), staff working with them (Teacher Liaison Officers $^{8}$ (TLOs)) and school governing body (SGB) members. I carried out group interviews with two cohorts of grade 8 learners (generally aged 13-14) in 2002, who became grade 9 learners in 2003 (these were mainly learners not on the $\mathrm{RCL})$. I also interviewed teachers, heads of department (HoD) and the school principals / senior management team (SMT) in both years. In total I carried out 114 interviews in total (see Table 2). Semi-structured interview schedules were used and interviews recorded and transcribed verbatim. Ethical considerations were taken into account and the confidentiality and anonymity of participants ensured.

In terms of observations every RCL meeting that took place during my case study visits was observed; I recorded proceedings (later transcribing them) and wrote notes concurrently. The number of meetings varied between schools. It is possible my visits (and interest in RCLs) might have influenced the number of and discussion in meetings. By carrying out multiple interviews across two years and including observational data I hoped to ensure some reliability of findings.

Table 2: Numbers of interviews and observations

\begin{tabular}{|l|c|c|c|c|c|c|c|c|}
\hline & \multicolumn{9}{|c|}{ Interviews } & $\begin{array}{c}\text { Observation } \\
\text { s }\end{array}$ \\
\hline $\begin{array}{l}\text { Schoo } \\
\text { I }\end{array}$ & $\begin{array}{c}\text { Class } \\
\text { A }\end{array}$ & $\begin{array}{c}\text { Class } \\
\text { B }\end{array}$ & $\begin{array}{c}\text { SMT / } \\
\text { Principa } \\
\text { I }\end{array}$ & SGB & $\begin{array}{c}\text { RCL group } \\
\text { and/or Chair }\end{array}$ & TLO & $\begin{array}{c}\text { Teacher } \\
\text { /HoD }\end{array}$ & $\begin{array}{c}\text { RCL } \\
\text { meetings }\end{array}$ \\
\hline A & 5 & 3 & 5 & 1 & 2 & 2 & 8 & 2 \\
\hline B & 4 & 4 & 4 & 1 & 2 & 1 & 12 & 3 \\
\hline C & 4 & 1 & 4 & 1 & 2 & 2 & 9 & 1 \\
\hline D & 4 & 4 & 7 & 1 & 1 & 1 & 13 & 2 \\
\hline
\end{tabular}

Data analysis took place throughout the study. Data was coded around key concepts and fed into a NUDIST database. Coded data was read and themes which linked into the research focus began to develop. Observational data fed into data produced through interviews. The analysis section is shaped around the three themes that emerged through data analysis:

1. How are the RCLs working in practice in the four case study schools?

2. In what ways do the RCLs engage with learners' rights?

3. What role do adults play in mediating RCLs and why?

\section{Learner councils in practice in South Africa}

The councils were set up and functioned differently in the four schools as highlighted below:

${ }^{8}$ The TLO is expected to be the link between the RCL and staff. 
- School A had a two-tier RCL system: the executive had 15 members from grades 8 to 12 (elected from class representatives) and the class representative system had two elected learners from each class (around 70 members).

- The RCL in School B consisted of three reps per grade, and with five grades in the school, there were fifteen members on the council. As there were more than three classes per year, grade representatives were expected to represent the whole grade (including learners who were in different classes to them).

- The RCL in School C comprised of two elected representatives per class, from grades 7 to 12, and a smaller executive body which did not meet separately.

- School D did not have a RCL, but rather retained the school council they had had for a number of years. It consisted of three (elected) grade reps for each of the five grades, 20 prefects from grade twelve, five teachers who were grade heads, one teacher liaison officer (TLO), three deputy heads and the school principal. The chairperson alternated between the head boy and head girl (i.e. prefects). In addition the three grade reps also sat on a grade council which met twice a term and was made up of the class reps for that grade and chaired by the grade head. Each class had two reps and the grade reps were elected from those twelve class reps.

Table 3 highlights some of the key differences between the councils, their lines of accountability and institutionalised links to the wider learner populace. It indicates that School $D$ in particular has incorporated the school council within the structures and functions of the school to a much greater extent than the other case study schools. RCLs in Schools A, B and $\mathrm{C}$ are learner-run, but lack wider support and guidance.

Table 3: Summary of RCL activities

\begin{tabular}{|c|c|c|c|c|}
\hline & School A & School B & School C & School D \\
\hline $\begin{array}{l}\text { RCL mentioned in } \\
\text { school policy }\end{array}$ & No & No & No & Yes \\
\hline $\begin{array}{l}\text { Who is present in } \\
\text { meetings }\end{array}$ & $\begin{array}{lr}\mathrm{RCL} \text { reps; } & \mathrm{TLO} \\
\text { (sometimes) } & \end{array}$ & $\begin{array}{l}\mathrm{RCL} \text { and } \\
\text { (sometimes) }\end{array}$ & RCL and TLO & $\begin{array}{l}\text { Council reps; } \\
\text { teachers; } \\
\text { management; } \\
\text { prefects; TLO. }\end{array}$ \\
\hline $\begin{array}{l}\text { Representatives } \\
\text { obliged to attend } \\
\text { meetings }\end{array}$ & No & No & No & Yes \\
\hline Who calls meetings & RCL exec and staff & RCL and TLO & $\mathrm{RCL}$ & $\begin{array}{l}\text { Regular meetings } \\
\text { set into timetable }\end{array}$ \\
\hline $\begin{array}{ll}\text { Frequency of } \\
\text { meetings }\end{array}$ & Irregular / ad hoc & Irregular / ad hoc & $\begin{array}{l}\text { Very irregular / freq. } \\
\text { cancelled }\end{array}$ & $\begin{array}{l}\text { Regular (once a } \\
\text { term) }\end{array}$ \\
\hline $\begin{array}{ll}\text { Meetings take } \\
\text { place }\end{array}$ & $\begin{array}{ll}\text { Lunchtime } & \text { (c.20 } \\
\text { mins) } & \\
\end{array}$ & $\begin{array}{ll}\text { Lunchtime } & \text { (c.30 } \\
\text { mins) } & \\
\end{array}$ & $\begin{array}{ll}\text { Lunchtime } & \text { (c.30 } \\
\text { mins) } & \end{array}$ & $\begin{array}{ll}\text { After school (one } \\
\text { hour) }\end{array}$ \\
\hline $\begin{array}{l}\text { Who has input onto } \\
\text { agenda }\end{array}$ & $\begin{array}{l}\text { Exec; class reps; } \\
\text { learners; teachers }\end{array}$ & RCL reps; TLO. & $\begin{array}{l}\text { RCL reps; SGB; } \\
\text { staff. }\end{array}$ & $\begin{array}{l}\text { Council reps; } \\
\text { learners; teachers; } \\
\text { management; } \\
\text { SGB; prefects. }\end{array}$ \\
\hline $\begin{array}{l}\text { Agendas prepared } \\
\text { / distributed }\end{array}$ & Sometimes & No & No & Yes \\
\hline $\begin{array}{l}\text { Minutes taken and } \\
\text { distributed }\end{array}$ & $\begin{array}{l}\text { Taken on ad hoc } \\
\text { basis }\end{array}$ & $\begin{array}{l}\text { Taken on ad hoc } \\
\text { basis }\end{array}$ & $\begin{array}{l}\text { Taken } \\
\text { distributed }\end{array}$ & $\begin{array}{lr}\text { Taken } & \text { and } \\
\text { distributed } & \text { by } \\
\text { prefect } & \end{array}$ \\
\hline $\begin{array}{l}\text { Informal / formal } \\
\text { meeting rules }\end{array}$ & Informal & Informal & Informal & Formal \\
\hline $\begin{array}{ll}\text { Training } & \text { of } \\
\text { representatives }\end{array}$ & $\begin{array}{l}\text { Small number older } \\
\text { learners by WCED }\end{array}$ & $\begin{array}{l}\text { Small number older } \\
\text { learners by WCED }\end{array}$ & $\begin{array}{l}\text { Small number older } \\
\text { learners by WCED }\end{array}$ & $\begin{array}{l}\text { Internal training for } \\
\text { all council reps. }\end{array}$ \\
\hline
\end{tabular}




\begin{tabular}{|l|l|l|l|l|}
\hline $\begin{array}{l}\text { Time allocated for } \\
\text { representatives to } \\
\text { talk to ss } \\
\text { before/after } \\
\text { meetings }\end{array}$ & No & No & No \\
\hline $\begin{array}{l}\text { Obligation for staff/ No } \\
\text { SGB to respond to } \\
\text { meeting 'decisions' }\end{array}$ & $\begin{array}{l}\text { Obligation for reps } \\
\text { to talk to learners } \\
\text { before after } \\
\text { meetings }\end{array}$ & No & No & Yes \\
\hline $\begin{array}{l}\text { RCLs able to make } \\
\text { decisions No }\end{array}$ & No & No & Yes \\
\hline $\begin{array}{l}\text { Main school } \\
\text { decision-making } \\
\text { body in school }\end{array}$ & $\begin{array}{l}\text { Principal and } \\
\text { teachers }\end{array}$ & $\begin{array}{l}\text { Principal and } \\
\text { teachers SLT and SGB }\end{array}$ & SLT and SGB \\
\hline
\end{tabular}

Table 3 also indicates that in Schools A, B and C the processes and functions of the RCLs were not institutionally embedded within the schools. There was no formal space for RCL representatives to speak to learners they represented, it was possible (and frequent) for learner representatives in these schools to miss meetings, not relay back information to learners and not gather information from learners. Representatives in these schools talked about feeling too intimidated to speak to fellow learners, partly because they were afraid of (asking) their teachers, with few teachers appearing to encourage the representatives' interactions with classmates. In practice learners in Schools B had no interaction with RCL representatives and learners in school $C$ had very little; and in School $A$ learners had had interaction with RCL representatives in 2002, but not in 2003. An example of the lack of engagement in can be seen in an interview abstract for School B:

Interviewer (I): Tell me about the RCL?

Learner (ST): We don't know who is the RCL...

ST: $\quad$ We know nothing of the RCL.

ST: $\quad$ We don't know who is the RCL, we don't feel that we are represented by other people... (School B, 2003).

These findings tie in with research from Carr (2005) whose questionnaire response from learners indicated poor or limited relations between representatives and learners in about half of responding schools. Indeed, Carrim (2011:76) (in relation to SGBs) notes that the 'gap between the representative and representative is ignored' in policy and calls for better ways to ensure representatives represent the 'voices' of those they represent (Carrim, 2011:81).

Contrastingly, there was an obligation and responsibility on class representatives in School D to attend meetings and interact with fellow learners. Time was allocated in class-teacher periods for representatives to talk to learners. Issues raised at the class level were initially discussed at the grade council level and then voted on before going forward to the school council. Grade assembly meetings took place twice a term in order to feedback information from school council meetings. All learners interviewed in School D said they had had interaction with their council representatives.

In terms of meeting content, Table 4 outlines the range of topics discussed (or those that had been previously discussed) in councils in the four schools and who was known to have raised the topic for discussion. 
Table 4: Agenda setting and topics of discussion in council meetings

\begin{tabular}{|c|c|c|c|c|}
\hline & School A & School B & School C & School D \\
\hline $\begin{array}{c}\text { Corporal } \\
\text { punishment }\end{array}$ & $\mathrm{X}^{*}$ & & & \\
\hline Teacher behaviour & $\mathrm{X}^{*}$ & & & \\
\hline Learner behaviour & $\mathrm{X}^{\star \star}$ & $\mathrm{X}^{\star \star \star \star} /{ }^{\star \star}$ & & $\mathrm{X}^{\star \star}$ \\
\hline School sports & $X^{*}$ & $\mathrm{X}^{\star \star \star \star}$ & & $\begin{array}{c}\mathrm{X}^{*} \\
\text { (intro. of soccer) }\end{array}$ \\
\hline Tuck shop & $\mathrm{X}^{*}$ & & & $\mathrm{X}$ \\
\hline $\begin{array}{l}\text { School gate } \\
\text { closure }\end{array}$ & $X^{\star *}$ & & & \\
\hline School bus & $\mathrm{X}^{*}$ & & & \\
\hline $\begin{array}{l}\text { Camp for RCL } \\
\text { members }\end{array}$ & $\mathrm{X}^{\star \star \star \star}$ & $X^{\star \star \star \star}$ & & \\
\hline School clean up & $X$ & $X$ & & \\
\hline School uniform & & $X$ & & $\mathrm{X}^{*}$ \\
\hline $\begin{array}{l}\text { Consultation on } \\
\text { school policy }\end{array}$ & & $\begin{array}{c}\mathrm{X}^{\star \star} \\
\text { (Code of Conduct) }\end{array}$ & $\begin{array}{c}\mathrm{X}^{* *} \\
\text { (Code of Conduct, } \\
\text { Mission Statement) }\end{array}$ & $\mathrm{X}^{\star *}$ \\
\hline $\begin{array}{c}\text { Organising school } \\
\text { events }\end{array}$ & & $\mathrm{X}^{\star \star \star \star *}$ & $\mathrm{X}^{\star \star \star \star *}$ & \\
\hline School fundraising & & & $\mathrm{X}^{\star \star \star}$ & \\
\hline $\begin{array}{l}\text { Religion in } \\
\text { assemblies }\end{array}$ & & & & $\mathrm{X}^{*}$ \\
\hline $\begin{array}{l}\text { Learners wearing } \\
\text { hair braids }\end{array}$ & & & & $X^{*}$ \\
\hline Litter & & & & $X$ \\
\hline $\begin{array}{l}\text { School buildings / } \\
\text { grounds }\end{array}$ & $X^{* *}$ & & & $\mathrm{X}^{* * / *}$ \\
\hline Safety issues & & & & $X$ \\
\hline $\begin{array}{l}\text { Learners attending } \\
\text { sporting events }\end{array}$ & & & & $X^{\star \star}$ \\
\hline $\begin{array}{l}\text { Introduction of } \\
\text { Founders Day }\end{array}$ & & & & $\mathrm{X}^{*}$ \\
\hline
\end{tabular}

The council in School D had a greater range of discussion than in other schools and School $\mathrm{C}$ the least. There is a particular focus of discussion on learner behaviour (e.g. through the Code of Conduct, litter) and events. Rights-based issues are raised in Schools A and D (corporal punishment, religion, hair braids) but not evident in Schools B and C. Findings in Table 4 tie in with previous research on RCL activities - where there was an emphasis on learner discipline, prevention of crime, assisting policy development, events, the school environment, fundraising and community outreach (Thuthukani Solutions, 2003; Carr, 2005, Mabovula, 2009; Phaswana, 2010; Carr and Williams, 2009). Questionnaire responses from Thuthkani Solutions (2003) suggest minimal use of the RCL as a body to engage with and claim rights.

With regard to who has input into meetings, the results from Table 4 are stark. While learners have input onto the agenda of RCL meetings in schools $A$ and $D$, they had seemingly no inputs onto the agenda of meetings in schools $B$ and $C$. Staff had a role in influencing RCL discussion in all schools. In particular they raised agenda items on learner discipline in all four schools (including Code of Conduct) and school buildings and grounds (Schools A and D). The TLO 
who sat in on meetings (though not always in Schools $A$ and $B$ ) at times dictated the agenda of meetings. The following extract shows the TLO of school B at the beginning of one meeting:

TLO: $\quad$ There are two things that I want you people to discuss and address and that is the Code of Conduct and what the RCL can do so everyone can get to know the Code of Conduct, because the whole school population is going out of order ... What can you do as the RCL to make sure that it gets implemented?

Staff in School D were active participants in council meetings. Not only did they regularly introduce items onto the agenda, but management in particular seemed to shape the direction of discussion. According to the TLO, management often 'direct(ed) the decisions ... in the way that they want to be made' and a learner representative observed that:

Representative: $\operatorname{Mr} \mathrm{C}$ (the principal) ... doesn't often say much, $\mathrm{Mr} \mathrm{B}$ (the deputy) ... is the one who butts in everywhere and says no I don't think so, or yes. And Mr C... he sorts of wraps up things closer to the end and puts his view forward, yes.

In two of the schools (Schools A and B) the TLO was the main link between the council and staff and had a crucial responsibility in terms of communicating messages from the RCL to teachers and management. In this system the TLO in both schools was able to determine whether to pass information on to staff and what information to take forward. According to the principal of School A the dialogue between staff and TLO was often not taking place, and the TLO in 2003, in particular, seemed to have limited interaction with both learners and staff. In School B, the TLO explained how he 'weighs up' whether to pass on or follow up on RCL meetings and the RCL chair described how some issues were not taken forward or discussed by staff. The quote below highlights problems with this system in School B.

Chair: $\quad$ Mr M (the TLO) has all our complaints, and I don't know what they are doing about it ... so this is the problem we need to sort out once again (School B, 2003).

In all cases staff mediated the outcomes of RCL meetings with most 'decisions' related to RCL discussions being made by external 'authorities' (i.e. the SGB, principal and/or teachers). In Schools A, B and C there was no institutional responsibility for staff to respond or act on information from RCL meetings, and whether this happened appeared to vary. Often staff denied or ignored RCL requests. In 2003 the RCL Chair in School B noted that he was still waiting for a response from management and heads of department after two meetings he had had with them over six months previously. The following extracts from schools $A$ and $C$ indicate a tendency for staff to refuse or deny RCL requests.

I: $\quad$ So what status do you have in the school, do the teachers see you as a really strong, powerful body or.... You are shaking your head, what do you mean?

Representative: I don't think they see us as much ... because in everything we try to come up they always overpower us, if we come up with something maybe they will disagree with us and come up with something else (school A, 2003).

With reference to the principal's response to requests and ideas from the RCL (School C, 2002):

Chair: It's always like no.

11 
$\begin{array}{ll}\text { I: } & \text { No? } \\ \text { Chair: } & \text { No. }\end{array}$

The TLO concurs:

TLO: $\quad$ They are toothless (the RCL), they don't have teeth, I'm trying to say they don't have much power... (School C, 2003).

So while the principal in School $C$ kept a hands-off approach in terms of meetings, he was exercising full control over potential outcomes and outputs. The principal claimed he did not want to interfere in the democratic process of the RCL, but his authority over decision-making shaped many of its practices. In School A teachers' influence came in their ability to interpret decisions made. In School A, while the RCL was perceived to challenge teacher authority, teachers were able to determine how to interpret $R C L$ requests (see Section: 6).

In School D the situation was different as the school council was consulted on issues and were allowed to make decisions on minor things (e.g. school tuck shop, school building and grounds). But other, bigger issues (that influenced school identity, policy, etc.) were referred onto management or the SGB, who made decisions. One deputy interviewed claimed, 'we try to find ways where we can get them to be involved and to feel that they are able to make a contribution', but acknowledged that the school 'is not' and 'cannot be' democratic. He stated:

Deputy: It isn't a great decision-making body, its powers are very circumscribed. And that's the nature of schools I'm afraid schools are generally hierarchical in structure, and RCLs wherever they may be, even in the most egalitarian schools, their powers are circumscribed (School D).

In this set up, the representatives and learners I interviewed thought they had a voice within the school, if they chose to engage, but recognised the limits. One representative stated that:

Representative: We do have a say, but basically they make the decisions ... because the school council is just a forum for discussion really and bringing up problems, and it's taken to the Board of Governors for the decision (School D).

Wyness (2009: 398) suggests school management can marginalise learners' voice by 'ensuring that schools have a functioning school council that deals only with peripheral issues'. This isn't necessarily the case in School D (learners can and do raise 'big' issues), but the decision-making processes relegate learners' influence.

This discussion has highlighted a number of practices in relation RCLs in four case study schools. Table 5: AnalysisTable 5 attempts to analyse the school data against Lundy's (2007) conceptualisation of children's right to voice. It suggests that while none of the schools are enabling learners' rights to voice, Schools A and D come closest (with both schools having similar histories of engagement see: Table 1). Schools B and $C$ have made little progress in realising learners' right to voice.

Table 5: Analysis learners' voice

\begin{tabular}{|l|lr|lr|lr|lr|}
\hline & School A & School B & School C & \multicolumn{2}{l|}{ School D } \\
\hline Space & $\begin{array}{l}\text { Outside } \\
\text { formal }\end{array}$ & sCL no & Outside & RCL no & Outside & RCL no & Safe & spaces \\
& formal & spaces & formal & spaces & provided & to give \\
& provided & and & provided & and & provided & and & opinions, & but \\
\hline
\end{tabular}




\begin{tabular}{|c|c|c|c|c|}
\hline & $\begin{array}{l}\text { spaces not seen as } \\
\text { safe }\end{array}$ & $\begin{array}{l}\text { spaces not seen as } \\
\text { safe }\end{array}$ & $\begin{array}{l}\text { spaces not seen as } \\
\text { safe }\end{array}$ & $\begin{array}{ll}\text { meetings include } \\
\text { adults }\end{array}$ \\
\hline Voice & $\begin{array}{l}\text { Outside RCL limited } \\
\text { facilitation of } \\
\text { learner voice. }\end{array}$ & $\begin{array}{lr}\begin{array}{l}\text { Outside } \\
\text { RCL }\end{array} & \text { no } \\
\text { facilitation } & \text { of } \\
\text { learner voice } & \end{array}$ & $\begin{array}{lr}\begin{array}{l}\text { Outside } \\
\text { facilitation }\end{array} & \text { no } \\
\text { learner voice } & \end{array}$ & $\begin{array}{l}\text { Learners } \\
\text { encouraged } \\
\text { express views }\end{array}$ \\
\hline Audience & $\begin{array}{lr}\text { Teachers } & \text { provide } \\
\text { audience } & \text { for } \\
\text { learners' } & \text { views, } \\
\text { mediated by TLO }\end{array}$ & $\begin{array}{l}\text { TLO mediates } \\
\text { learners ideas; } \\
\text { some meetings with } \\
\text { teachers/ SMTs; } \\
\text { not formalised }\end{array}$ & $\begin{array}{ll}\text { Principal provides } \\
\text { audience }\end{array}$ & $\begin{array}{l}\text { School councils' } \\
\text { views taken to SMT } \\
\text { and } \\
\text { Formalised } \\
\text { channels } \\
\text { communication of }\end{array}$ \\
\hline Influence & $\begin{array}{l}\text { Limited - although } \\
\text { some rhetoric of } \\
\text { change Adults are } \\
\text { decision makers }\end{array}$ & $\begin{array}{l}\text { No evidence of } \\
\text { influence }\end{array}$ & $\begin{array}{l}\text { No evidence } \\
\text { influence }\end{array}$ & $\begin{array}{l}\text { Influence on minor } \\
\text { issues, no evidence } \\
\text { of influence on more } \\
\text { significant decisions }\end{array}$ \\
\hline
\end{tabular}

In the next section I look at the extent to which councils were used to promote learners' other rights.

\section{RCLs and Learners' Rights}

The paper also explores evidence of other rights being claimed through learner councils. In each of the four schools learners had a number of rights-based concerns which came out through interview discussions. Learners knew of their legal rights and saw they weren't always substantively enabled within their school. I wanted to see whether a formal space for learner voice (i.e. the RCL) would help learners claim their legal rights. I look at the rights-based concerns raised in interviews by learners in Table 6 , and indicate whether these had been raised for discussion in RCL meetings. The rights-based concerns learners raised in interviews are noted with an $\mathrm{X}$ and whether these concerns had been discussed in RCL meetings is indicated in brackets (yes/no).

Table 6: Rights-based concerns of learners (versus RCL agendas)

\begin{tabular}{|c|c|c|c|c|}
\hline & School A & School B & School C & School D \\
\hline \multicolumn{2}{|c|}{ Related to corporal punishment / abuse } & \\
\hline $\begin{array}{c}\text { Corporal } \\
\text { punishment }\end{array}$ & X (yes) & X (no) & X (no) & \\
\hline $\begin{array}{c}\text { Teachers calling } \\
\text { learners names }\end{array}$ & X (yes) & X (no) & \\
\hline \multicolumn{4}{|c|}{ Related to teaching and learning } & \\
\hline $\begin{array}{c}\text { Lack of cover / } \\
\text { inadequate } \\
\text { teaching }\end{array}$ & X (no) & X (no) & \\
\hline $\begin{array}{c}\text { Teachers late to } \\
\text { class / left class } \\
\text { during lessons }\end{array}$ & X (yes) & X (no) & & \\
\hline $\begin{array}{c}\text { School early } \\
\text { closure for staff } \\
\text { meetings / payday }\end{array}$ & X (no) & & & \\
\hline $\begin{array}{c}\text { School gate } \\
\text { closure11 }\end{array}$ & X (yes) & X (no) & & \\
\hline
\end{tabular}

\footnotetext{
${ }^{9}$ E.g. monkey, baboon, stupid and dumb

${ }^{10}$ This included teachers missing classes (sometimes for a whole term) and learners having little or no cover. It also included inadequate resources.

${ }^{11}$ Schools often lock gates to prevent intruders. In school B learners complained staff would not let latecomers in and they could be sent home. This adversely affected those living further away i.e. black learners. 


\begin{tabular}{|c|c|c|c|c|}
\hline School bus & $\mathrm{X}$ (yes) & & & \\
\hline \multicolumn{5}{|c|}{ Related to culture / race / identity / religion rights } \\
\hline Religion in school ${ }^{12}$ & & & $\mathrm{X}(\mathrm{no})$ & $\mathrm{X}$ (yes) \\
\hline $\begin{array}{l}\text { Learners wearing } \\
\text { hair braids }\end{array}$ & & & & X (yes) \\
\hline $\begin{array}{l}\text { Perceived racism / } \\
\text { racial difficulties }\end{array}$ & & $X(n o)$ & $X($ no) & \\
\hline School sports & $X$ (yes) & $\mathrm{X}$ (yes) & $\mathrm{X}(\mathrm{no})$ & $X$ (yes) \\
\hline
\end{tabular}

The RCL had been used by learner representatives and learners in only two (schools $A$ and D) of the four schools to discuss and claim learner rights, even though learners within the two other case study schools ( $B$ and $C$ ) outlined a range of concerns they had (these included the use of corporal punishment, perceived racism, teachers verbally abusing learners and issues with access to education). The RCL system had not picked up these concerns, nor had learners felt able to raise them on these bodies.

In School A the RCL called for teachers to stop using corporal punishment claiming this was a violation of their rights. Here the RCL challenged educators, their institutionalised positions and traditional notions of schooling relations in pursuit of their rights. Learners' 'place' within the social structure of the school (Wyness, 2009), meant teachers were able to determine how to interpret their claim. Some teachers adapted their behaviour as a result of the interaction with the RCL, whilst others continued to practice corporal punishment. For those teachers using corporal punishment many used 'culture' as a justification - stating that in 'African culture' beatings and punishment were part of a process of respect and learning for children. Here the TLO suggested that African culture was used by teachers to de-legitimate the notion of learner voice, using it to claim the importance of adult views over children's. It also undermines the power of 'rights' as a tool for equality and equity.

Learners in school $D$ raised a number of rights-based issues which got onto the agenda of school council meetings. These included the religious nature and content of assemblies, going to the mosque on Fridays (without missing lesson-time), soccer ${ }^{13}$ as a school sport and the wearing of hair braids. However, even in this enabling environment some issues were contentious, and learners described how they felt unable to raise certain subjects:

Representative: I just know things like soccer, don't bring soccer to school council, because they bring it to council every year, and every year they (staff) say no, so don't bring soccer.

Whilst discussed at council level, decisions about rights-based issues were made externally and the council appeared to have little influence over the outcome. For example, while the school council voted to allow hair braids and soccer as a school sport, the SGB and management refused them. After learners, teachers and school religious group leaders looked at the religious content of assemblies, it was management who had the final say about which adaptations to accept, the nature of the changes and those to reject. As Lundy (2007:937) contests, it is easy for adults to comply with the various outward signs of consultation and ultimately ignore children's views.

\footnotetext{
${ }_{12}$ In School D this was related to the perceived predominance of Christianity in the school, in School C the perceived predominance of Islam.

${ }^{13}$ A rights-based issue I would contend because traditionally in South Africa soccer/ football was not played in 'white' schools, but was played in black schools. 


\title{
7. Adult - learner relations and learner councils
}

Staff-learner relations were key to influencing how the councils functioned in the schools. Under apartheid and the Christian National Education (CNE) system, schools were hierarchical and authoritarian institutions (Eshak, 1987; Soudien, 1995) with social control a 'main mission' of schooling (Soudien, 1995). Staff were charged with developing learners who were expected to be subservient and accepting. Research (Bray and Moses, 2011; Carr and Williams, 2009) suggests this tension remains despite calls to democratise institutions:

\begin{abstract}
school principals are only exhibiting a "rhetorical commitment" to democratic deliberations. Grant (2006:525-526) attributes this affinity for autocratic leadership on the part of South African school principals to factors like an authoritarian mentality, fear of the loss of power, school cultures that are steeped in deeply ingrained attitudes, values and skills as well as ethnic, cultural and gender biases (Carr and Williams, 2009: 79).
\end{abstract}

In all case study schools there was evidence of tension between staff and learners, where historical notions of authority and hierarchy were pitted against newer calls to democratise and equalise. In relation to learner councils these tensions potentially inhibited and/or shaped how learners' voice was heard and to some extent whether rights were claimed and supported/substantiated. In particular staff appeared wary of disrupting traditional hierarchies in schools (where the teacher had authority) in favour of a system which gave learners 'authority'. As such, learner voice needed to be managed and given boundaries. This tension can be seen in terms of the status of councils, how they were able to function, how staff shaped agendas, how decisions were made in the schools and the extent to which teachers encouraged council representatives space within the timetable. For example:

I: I have heard that some reps have no interaction with the classes...

RCL Chair: $\quad$ Yes, because sometimes the reps don't talk sometimes because they are scared and sometimes they are a bit scared of the teachers, because the teachers don't like their role sometimes (School B).

The tension can also be seen in school $C$ in the hands-off approach taken by staff, which absolves them of responsibility to ensure the RCL is functioning in a way which enables learner voice or participation.

Principal: $\quad$ There is very little we can do, simply because it's a body which is supposed to function independent of any interference (School C).

It can also be seen in the decision by staff in School $D$ to retain a school council system, as opposed to a learner-only RCL. This decision was made in order to put 'a cap on radicalism' (deputy, school D) as it was perceived an RCL might:

Deputy: be more likely to consider their prefects as the enemy, or the school management (School D).

Or:

TLO: running the schools would be impossible, because you would have a pupilbody that could be in constant loggerheads with the teacher body (School D). 
Not only is learner voice contested because of its perceived 'threat' to authority, there is also rebuff on the grounds of learners' age and subsequent perceived lack of wisdom (see Frankin, 1989) in School A:

TLO: $\quad$ Because, we haven't got much democratic enough to give them their say and listen properly to their say and not be judgemental that we are older than them, so ..., we have comments that say, we can't be told by students what to do, we still have those from teachers, then there's management and then there's parents (School A).

In schools B, C and D a prefect body remained (although not all in line with legal requirements). For staff, the prefect system was seen as supportive of staff and school discipline, whereas learner councils were potentially 'contesting authority', being independent and 'antagonistic' (teachers, School D). Interviews suggest reluctance from staff to support RCLs and the continued perceived importance of prefect bodies.

\section{Summary and discussion}

This paper describes how government policy to install learner-only councils in each secondary school in South Africa was being translated into practice in four case study schools and the tensions which surfaced. In general the schools complied with their legal obligations but learners were limited in their potential to voice ideas, have an audience and make decisions. The research has shown us that while RCLs are learners' 'spaces', they are located within hierarchical places where learners have little authority. The tension between learners who now have legal rights and space for voice and the perceived threat this poses to the identity and authority of staff can be seen in each of the schools.

It raises questions (previously drawn together by Howard, 2005) as to whether authoritative institutions can embrace learner voice and active citizen engagement. In the case study schools 'democracy' was paid lip service through the election of council representatives and the establishment of the council spaces, but the established hierarchical relations in the schools prevailed in what councils discussed, how they were received and the outcomes of meetings. How 'democracy' and voice played out was different in the four schools, with histories of learner's engagement influencing the current practice. Schools A and D had historical engagement with learner/school councils and voice which continued in similar forms. Schools B and C had little identified historical engagement with student voice and learner/school council, and while the councils now exist, their lack of 'voice' within schools remains evident. Subsequently, it was only in Schools A and D that rights-based claims were made via the councils, despite perceived violations of rights in Schools B and C.

In policy terms the desire to establish learner-led RCLs in each secondary school seems impressive. But the research has shown here that deeply engrained schooling practices inhibit their potential. Without some sort of shift in schooling relations away from that of adult-learner distrust, towards adult-learner respect the ambition of the policy will continue to be limited. Moreover, I would argue the policy guidance for RCLs lacks scope and provides confusing messages for schools, especially in relation to learners' voice. A more ambitious set of guidance might send out a clearer message to schools about their obligations towards learner' voice. But ultimately, the realisation of learner voice in schools will be linked to changing adults' perceptions of its value. This is not only relevant to the context of South Africa, but relates to practices around school councils more generally. 


\section{References}

Baginsky, M. \& Hannam, D. (1999) School Councils: the views of students and teachers summary of findings. London, NSPCC.

Bragg, S. (2007) "Student Voice" and Governmentality: The production of enterprising subjects? Discourse: Studies in the Cultural Politics of Education, 28, (3), pp.343-358.

Bray, R. and S. Moses (2011) Children and participation in South Africa: Exploring the landscape. Perspectives in Education, Vol. 29 (1), pp.5-17.

Carr, I. \& C. Williams (2009) The mediation of Representative Council of Learners policy in Western Cape schools - 1997 to 2003. South African Journal of Education, 29, pp.69-82

Carr, I. (2005) From Policy to Praxis: A study of the implementation of representative councils of learners in the Western Cape, from 1997 to 2003. Unpublished PhD thesis. Cape Town: University of the Western Cape.

Carrim, N. (2011) Modes of Participation and Conceptions of Children in South African Education. Perspectives in Education, Vol. 29 (1), pp.74-82.

City of Cape Town (2011) Census.

http://www.capetown.gov.za/en/stats/Pages/Census2011.aspx [Accessed October 2013].

City of Cape Town (2001) Census.

http://www.capetown.gov.za/en/stats/2001census/Pages/default.aspx [Accessed October 2013].

Department of Education (1996) South African Schools Act. Pretoria, Government Printer.

Education Human Resources (1999) Representative Council of Learners: roles and responsibilities. Pretoria, Department of Education.

Eshak, Y. (1987) Authority in Christian National Education and Fundamental Pedagogies. MEd. dissertation, University of Witswatersrand.

Fielding, M. (1973) Democracy in secondary schools: school councils and 'shared responsibility'. Journal of Moral Education, 2(3), pp.221-232.

Franklin, B. (1989) Children's rights: developments and prospects. Children and Society, 3, (1), pp.50-66.

Halstead, M. \& Taylor, M. (2000) The Development of Values, Attitudes and Personal Qualities: a review of recent research. Slough, NFER.

Hannam, D. (2003) Student Councils and Education for Democracy in English Secondary Schools (draft). London, New Politics Network.

Howard, B. (2005) Student reflections: Student councils. Citized. www.citized.info/pdf/students/Ben_Howard.pdf [Accessed September 2013]. 
Hunt, F. (2007) Schooling citizens: Policy in practice in South Africa. Unpublished DPhil thesis. Brighton: University of Sussex.

Hunt, F. (2011) Schooling citizens: Policy in practice in South Africa. Compare, 41, (1), pp.4358.

Jamieson, L. Pendlebury, S. and R. Bray (2011) Children as citizens. In: Jamieson L, Bray R, Viviers A, Lake L, Pendlebury S \& Smith C (eds) South African Child Gauge 2010/1. Children's Institute, University of Cape Town.

Lister, R. (1998) Citizenship on the margins: citizenship, social work and social action. European Journal of Social Work 1(1), pp.5-18.

Lundy, L. (2007) 'Voice' is not enough: conceptualising Article 12 of the United Nations Convention on the Rights of the Child. British Educational Research Journal, Vol. 33, (6), pp. 827-942.

Mabovula, N. (2009) Giving voice to the voiceless through deliberative democratic school governance. South African Journal of Education, 29, pp. 219-233.

Naidoo, J. (2005) Educational decentralization and school governance in South Africa: from policy to practice. Paris: UNESCO/IEEP.

Pendlebury, S. (2011) Children and school governance: Representation, participation and power. . In: Jamieson L, Bray R, Viviers A, Lake L, Pendlebury S \& Smith C (eds) South African Child Gauge 2010/1. Children's Institute, University of Cape Town.

Phaswana, E. (2010) Learner councillors' perspectives on learner participation. South African Journal of Education, 30, pp.105-122.

Pryor, J., Ampiah, J., Kutor, N. \& Boadu, K. (2003) Student Councils in Ghana and the formation of the liberal democratic citizen. In: Mutua, K. \& Sunal, C. eds. Forefronts of Research. Greenwich CT, Information Age Publishing.

Republic of South Africa (RSA) (2006) Children's Act. Pretoria: Government Gazette.

Republic of South Africa (RSA) (1996) Constitution

Soudien, C. (1995) Apartheid and education: coping with difference in South Africa. In: American Educational Research Association Annual Meeting, April 1995, San Francisco.

Stake, R. (1994) Case studies. In: Denzin, N. \& Lincoln, Y. eds. Handbook of Qualitative Research. London, SAGE Publications Ltd, pp.86-109.

Taylor, M. \& Johnson, R. (2002) School councils: their role in citizenship and personal and social education. Available from: http://www.nfer.htmldocs/html/Outcome SCS.html [Accessed 6 March 2003].

Thuthukani Solutions (2003) Representative Council of Learners. Report on the conference held for schools in the Western Cape 30 June to 2 July 2003. Cape Town, WCED. 
United Nations (UN) (1989) United Nations Convention on the Rights of the Child (UNCRC). Geneva: United Nations.

Usher, R. (1996) A critique of the neglected epistemological assumptions of educational research. In: Scott, D. \& Usher, R. eds. Understanding Educational Research. London, Routledge, pp.9-32.

Western Cape Education Department (WCED) (1997) Provincial Gazette Extraordinary 5136. Cape Town: WCED.

WCED (2003) Provincial Gazette Extraordinary 5946. Cape Town: WCED.

WCED (2013) ‘Find a School'. http://wcedemis.pgwc.gov.za/wced/findaschool.html [Accessed October 2013].

Whitty, G. and E. Wisby (2007) Real decision making? School councils in action. London: DCSF.

Wyness, M. (2001) Children, childhood and political participation: Case studies of young people's councils. The International Journal of Children's Rights, 9, pp. 193-212.

Wyness, M. (2009) Adult's Involvement in Children's Participation: Juggling Children's Places and Spaces. Children and Society, 23, pp. 395-406 